\title{
AKTIVITAS ANTIMIKOSIS EKSTRAK ETANOL DAUN SIRSAK (Annona muricata L.)
}

\section{ANTIMYCOSIS ACTIVITY OF ETHANOLIC EXTRACT OF SOURSOP LEAVES (Annona muricata L.)}

\author{
Didi Rohadi \\ Akademi Farmasi Muhammadiyah Cirebon \\ Jl. Cideng Indah No. 03 Cirebon \\ Email: didiaskun@yahoo.co.id
}

Submitted: 03-12-2015

Reviewed: 29-01-2016 Accepted: 26-04-2016

\begin{abstract}
ABSTRAK
Prevalensi kandidiasis di masyarakat cukup tinggi. Beberapa antimikosis sudah kurang efektif sehingga perlu dieksplor sumber-sumber baru antimikosis, salah satu kandidatnya adalah daun sirsak (Annona muricata L.). Penelitian ini dilakukan untuk mengetahui aktivitas antimikosis ekstrak etanol daun sirsak pada konsentrasi 15\%, 30\%, dan 60\% terhadap Candida albicans ATCC 10231dengan metode difusi agar. Hasil penelitian memberikan informasi bahwa semua ekstrak etanol daun sirsak menunjukkan aktivitas antimikosis dengan potensi variatif tergantung konsentrasi.
\end{abstract}

Kata kunci: Annona muricata L., antimikosis, metoda difusi agar

\begin{abstract}
Prevalence of Candidiasis is still in high level. Some antimycosis have been less effective so it needs to explore novel sources of antimycosis, one of candidate is the soursop leaves (Annona muricata L.) The aims of this study to observe antimycosis activity of the ethanol extract of soursop leaves at concentration of $15 \%, 30 \%$, and $60 \%$ against Candida albicans ATCC 10231 with agar diffusion method. The results showed that all of the ethanol extract of soursop leaves have exhibited antimycosis activity which concentration-dependent.
\end{abstract}

Keywords: Annona muricata L., antimycosis, agar diffusion method

\section{PENDAHULUAN}

Infeksi fungi (mikosis) banyak dijumpai pada masyarakat di negara tropis termasuk Indonesia karena iklim yang panas dan lembab. Pada umumnya organisme penyebab infeksi fungi dan beriko tinggi adalah Candida spp. (Garnacho et al., 2012). Kandidiasis adalah infeksi primer atau sekunder dari genus Candida terutama Candida albicans. Penelitian di Surabaya pada tahun 2004 menunjukkan bahwa sebanyak 34,8\% kandidiasis vulvo vaginitis, disebabkan oleh Candida albicans. Pada tahun 2007, Candida albicans merupakan fungi yang paling banyak menyebabkan kandidiasis oral yaitu sebesar 35,29\% dibandingkan Candida spp. yang lain. Pada tahun 2011, sebanyak 85,7\% penderita kandidiasis vulvo vaginitis pasen AIDS disebabkan oleh Candida albicans (Suyoso, 2013).

Pada umumnya pengobatan kandidiasis menggunakan azoles, polyenes, and echinocandins (Abad, 2015). Penggunaan antifungi lokal maupun sistemik mempunyai kelemahan. Amfoterisin B mempunyai efek samping kerusakan ginjal (nefrotoksik). Nistatin tidak dapat memberikan efek sistemik. Beberapa antifungi sudah tidak efektif lagi digunakan karena faktor resistensi. Penelitian di Ilam-Iran oleh Mohamadi et al., (2015) menunjukkan bahwa 150 isolat Candida albicans telah resisten tehadap fluconazole, itraconazole, ketoconazole, clotrimazole, variconazole, posaconazole dan 
nistatin masing-masing sebanyak $76 \%, 62 \%, 72 \%, 55 \%, 6 \%, 7 \%$, dan $1 \%$. Data ini tidak diperoleh dari Indonesia, tetapi memberikan gambaran bahwa sebagian antifungi sudah tidak efektif lagi. Oleh karena itu, penemuan obat baru merupakan hal menarik untuk dilakukan. Salah satu sumber bahan baku obat kandidiasis berasal dari tumbuhan dan yang banyak diteliti adalah sirsak (Annona muricata L.),

Sirsak mempunyai banyak kegunaan, antara lain sebagai antibakteri, antifungi, antitumor, antikonvulsan, penenang, antiparasit, dan cardiodepresant (Taylor, 2002). Daun sirsak mengandung alkaloid, polifenol, terpen (Leboeuf, 1982), acetogenin (Wu et al., 1995), flavonoid (Kumar et al., 2012), dan lectin (Damico, 2003). Penelitian aktivitas antibakteri daun sirsak telah banyak dilakukan (Sari, 2010; Permatasari, 2013; Fitriani, 2014; Apriyuslim, 2015) sedangkan penelitian terhadap aktivitas antifungi masih kurang. Oleh karena itu, untuk menggali potensi antimikosis dari daun sirsak perlu dilakukan penelitian sehingga dapat menjawab masalah terkait aktivitas daun sirsak sebagai antimikosis terutama terhadap Candida albicans.

\section{METODE PENELITIAN}

Alat dan Bahan

Alat yang digunakan dalam penelitian ini adalah: satu set alat maserasi, vaccum rotary evaporator (IKA RV 10), pipet mikro (Boeco Germany), alat-alat gelas dan inkubator (Memert). Bahan yang digunakan adalah: daun sirsak yang diperoleh dari Kuningan Jawa Barat, berwarna hijau tua dipanen pada bulan Agustus 2014, Etanol 96\%, Candida albicans ATCC 10231 yang diperoleh dari Laboratorium Mikrobiologi Universitas Indonesia Jakarta, Nutrient agar (Oxoid), Tablet ketokenazol (Kimia Farma), dan $\mathrm{NaCl}$ fisiologis (Otsuka Indo).

\section{Jalannya Penelitian}

\section{Penapisan fitokimia}

Penapisan fitokimia terhadap daun sirsak dilakukan dengan metode Simes (Kusrahman, 2012) untuk mengetahui kandungan metabolit sekunder yaitu flavonoid, fenolik, saponin, terpenoid dan steroid sedangkan uji alkaloid dilakukan dengan metode Culvenor-Fitzgerald (Kusrahman, 2012).

\section{Pembuatan ekstrak}

Ekstrak daun sirsak dibuat dengan cara maserasi menurut Farmakope Indonesia III. Daun sirsak kering sebanyak 150 gram yang telah diserbuk direndam dalam $1125 \mathrm{ml}$ etanol $96 \%$ selama 5 hari dengan pengadukan setiap hari, selanjutnya disaring, residu diremaserasi. Ekstrak yang didapat dipekatkan dengan menggunakan vaccum rotary evaporator pada suhu $50^{\circ} \mathrm{C}$. Selanjutnya ekstrak kental diencerkan hingga didapatkan konsentrasi 15\%,30\%, dan $60 \%$.

\section{Pembuatan suspensi mikroba}

Mikroba uji dari kultur persediaan diinokulasikan pada media agar miring dan diinkubasikan pada suhu $37^{\circ} \mathrm{C}$ selama 24 jam. Selanjutnya, 2 ose hasil inkubasi diinokulasikan pada media Nutrien Broth dan dinkubasikan pada suhu $37^{\circ} \mathrm{C}$ selama 24 jam. Setelah diinkubasi, suspensi mikroba diencerkan dengan $\mathrm{NaCl}$ fisiologis hingga didapatkan transmitan $25 \%$ pada panjang gelombang 580 $\mathrm{nm}$.

\section{Pengujian antimikosis}

Pengujian aktivitas antimikosis dilakukan dengan metode difusi agar dengan menggunakan sumuran diameter $6 \mathrm{~mm}$. Suspensi mikroba sebanyak 0,2 $\mathrm{ml}$ dimasukkan ke dalam cawan petri. Kemudian ditambahkan media nutrient agar $\left(45^{\circ} \mathrm{C}\right)$ sebanyak $20 \mathrm{ml}$, digoyang-goyangkan dan dibiarkan memadat. Dengan bantuan perforator steril, dibuat sumuran sebanyak 5 lubang. Selanjutnya, setiap sumuran diisi dengan 0,020 ml ekstrak konsentrasi 15\%, 30\%, 60\%, etanol 96\% (kontrol negatif) dan larutan ketokenazol $1 \mathrm{mg} / \mathrm{ml}$ (kontrol positif). Pra-inkubasi dilakukan selama 30 menit 
pada suhu kamar, selanjutnya diinkubasi pada suhu $37{ }^{\circ} \mathrm{C}$ selama 24 jam. Diameter hambat pertumbuhan mikroba uji diukur.

\section{HASIL DAN PEMBAHASAN}

Hasil penapisan fitokimia terhadap daun sirsak ditampilkan pada Tabel I.

Tabel I. Hasil penapisan fitokimia ekstrak etanol daun sirsak Golongan Senyawa Kimia

\begin{tabular}{ccccc}
\hline Flavonoid & Fenolik & Alkaloid & Saponin & Steroid \\
\hline+ & + & - & + & -
\end{tabular}

Keterangan :

$+\quad=$ terdeteksi

- $\quad$ = tidak terdeteksi

Hasil penapisan fitokimia terhadap daun sirsak terdeteksi adanya senyawa flavonoid, fenolik dan saponin. Hal ini sesuai dengan penelitian Leboeuf, et al., (1982). Alkaloid dan steroid tidak terdeteksi. Hasil ini sama dengan penelitian Nuringtyas, et al., (2007).

Hasil uji antimikosis ekstrak etanol daun sirsak terhadap Candida albicans ditunjuk-kan pada Gambar 1 dan Tabel II.

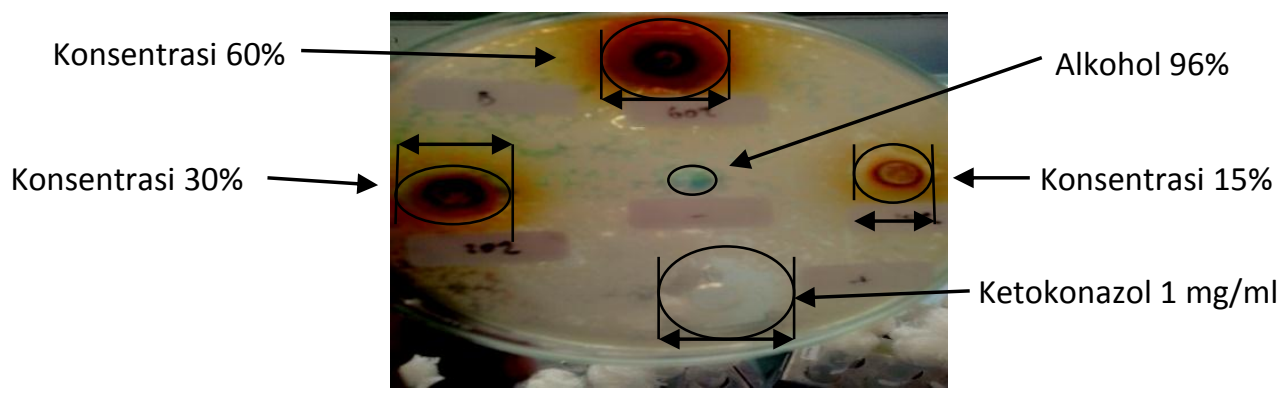

Gambar 1. Daerah hambat ekstrak etanol daun sirsak pada media nutrient agar yang diinokulasi Candida albicans ATCC 10231

Tabel II. Diameter daerah hambat ekstrak etanol daun sirsak terhadap pertumbuhan Candida albicans ATCC 10231

\begin{tabular}{cccccc}
\hline \multirow{2}{*}{$\begin{array}{c}\text { Pengujian } \\
\text { ke }\end{array}$} & \multicolumn{5}{c}{ Diameter Daerah Hambat (mm) } \\
\cline { 2 - 6 } & Etanol 96\% & Ketokonazol & \multicolumn{3}{c}{ Konsentrasi Ekstrak } \\
\cline { 4 - 6 } & & $1 \mathrm{mg} / \mathrm{ml}$ & $15 \%$ & $30 \%$ & $60 \%$ \\
\hline 1. & 0 & 22,82 & 13,17 & 14,80 & 16,10 \\
2. & 0 & 19,00 & 13,85 & 14,72 & 17,07 \\
3. & 0 & 18,07 & 12,07 & 14,42 & 15,80 \\
\hline Rata-rata & 0 & $19,96 \pm 2,06$ & $13,03 \pm 0,73$ & $14,64 \pm 0,16$ & $16,32 \pm 0,54$ \\
\pm SD & & & & & \\
\hline
\end{tabular}

Berdasarkan gambar dan Tabel di atas, ekstrak etanol daun sirsak dapat menghambat pertumbuhan Candida albicans ATCC 10231 pada konsentrasi 15\%,30\%, dan 60\% yang ditunjukkan dengan terbentuknya daerah hambat/bening di sekitar sumuran yang berisi ekstrak etanol daun sirsak. 
Hambatan terkecil diberikan pada konsentrasi $15 \%$ yaitu sebesar 13,03 mm. Pada konsentrasi yang lebih tinggi yaitu 30\% dan 60\%, hambatan pertumbuhan Candida albicans ATCC 10231 mengalami kenaikan masing-masing menjadi 14,64 mm dan 16,32 $\mathrm{mm}$. Semakin tinggi konsentrasi semakin besar daya hambatnya. Efek antimikosis ketokonazol sebagai kontrol positif ditunjukkan dengan daerah hambat sebesar 19,96 mm, sedangkan etanol 96\% sebagai kontrol negatif tidak memberikan hambatan. Hal ini menunjukkan bahwa hambatan yang diberikan oleh ekstrak adalah hambatan yang terjadi karena pengaruh kandungan senyawa dalam ekstrak.

Hasil analisis statistik menggunakan Anova yang dilanjutkan uji HSD menunjukkan bahwa terdapat perbedaan bermakna antara kontrol negatif dengan semua perlakuan. Artinya bahwa, ada perbedaan aktivitas antimikosis yang bermakna pada berbagai konsentrasi ekstrak etanol daun sirsak. Pada rentang konsentrasi yang digunakan pada penelitian ini, semakin tinggi konsentrasi, semakin besar daya hambat terhadap Candida albicans ATCC 10231.

Aktivitas antimikosis ini diperkirakan berhubungan dengan senyawa aktif yang terdapat pada ekstrak etanol daun sirsak yaitu senyawa fenolik. Flavonoid dan polifenol yang merupakan senyawa fenolik bersifat antisepsis dan desinfektan bekerja dengan cara denaturasi dan koagulasi. Turunan senyawa fenol juga dapat merusak permeabilitas membrane sel, sehingga dapat mengakibatkan kebocoran sel, dan mikroba akan mengalami kematian (Siswandono dan Soekardjo, 2008). Diduga kemampuan penghambatan Candida albicans oleh ekstrak etanol daun sirsak berhubungan dengan senyawa lektin yaitu kelompok senyawa protein-karbohidrat yang tersebar luas di alam termasuk salah satunya pada tanaman sirsak (Gomes, et. al,. 2012). Penelitian Gomes,et al., (2012) menunjukkan adanya aktivitas antifungi lektin terhadap jamur isolat sekret vagina yang salah satunya adalah Candida albicans. Mekanisme penghambatannya belum dapat dijelaskan, tetapi diperkirakan berhubungan dengan penghambatan germinasi spora untuk tumbuh menjadi miselium. Dinding sel fungi terganggu karena adanya perubahan sintesis kitin oleh lektin.

\section{KESIMPULAN}

Ekstrak etanol daun sirsak menunjukkan aktivitas antimikosis terutama terhadap Candida albicans. Pada rentang konsentrasi 15\% - 60\%, semakin tinggi konsentrasi ekstrak semakin besar aktivitasnya.

\section{UCAPAN TERIMAKASIH}

Ucapan terimakasih disampaikan kepada Akademi Farmasi Muhammadiyah Cirebon yang telah membiayai penelitian ini dan teman-teman dosen yang telah membantu dalam penelitian ini.

\section{DAFTAR PUSTAKA}

Abad, H.S.E., Zaini, F., Kordbacheh, P., Mahmoudi, M., Safara, M., Mortezaaee, V., 2015, In Vitro Activity of Caspofungin Against Fluconazole-Resistant Candida Species Isolated From Clinical Samples in Iran, Jundishapur Journal Microbiol, 8(6):1-4.

Apriyuslim, R.P., Wahdaningsih, S., Fitrianingrum, I., 2014, Uji Aktivitas Antibakteri Ekstrak Etanol Daun Sirsak (Annona muricata L.) terhadap Salmonella typhi secara in vitro, Skripsi, Program Studi Pendidikan Dokter Fakultas Kedokteran Universitas Tanjungpura.

Damico, D.C.S., Freire, M.G.M., Gomes, V.M., Toyama, M.H.,Marangoni, S., Novello, J.C., Macedo, M.L.R., 2003, Isolation and characterization of a lectin from Annona muricata seeds, Journal of Protein Chemistry. 22: 655-661.

Fitriani, E., Wahdaningsih, S., Rialita, A., 2014, Uji Aktivitas Antibakteri Ekstrak Etanol Daun Sirsak (Annona muricata L.) terhadap Shigella flexneri secara in vitro, Skripsi, Program Studi Pendidikan Dokter Fakultas Kedokteran Universitas Tanjungpura.

Garnacho, M.J., Diaz, M.A., Ruiz, P.D.P.M., Garcia, Cabrera E., 2012, Invasive Fungal Infection in Critically ill Patiens, Enferm Infecc Microbiol Clin. 30 (6): 38-43.

Gomes, B.S., Siquiera, A.B.S., Maia, R.C.C., Giampaoli, V., Teixeiras, E.H., Arrudas, F.V.S., Nascimento, K.S., Lima, A.N., Motta, C.M.S., Cavada, B.S., Porto, A.L.F., 2012, Antifungal 
Activity of Lectins Against Yeast of Vaginal Secretion, Brazilian Journal of Microbiology: 770-778.

Hoehamer, C.F., Cummings, E.D., Hilliard, G.M., Rogers, P.D., 2010, Changes in the proteome of Candida albicans in response to azole, polyene, and echinocandin antifungal agents. Antimicrob Agents Chemother. 54(5):1655-1664.

Kumar, N., Rajkumar, V., Suresh, P.K., Kumar, R.A., Cijo, G.V., 2012, Quantitative Assesment of the Relative Antineoplastic Potensial of the n-butanolic Leaf Extract of Annona Muricata Linn. In Normal and Immortalized Human Cell Lines, Asian Pacific Journal of Cancer Prevention, Vol.13: 699-703.

Kusrahman, A., 2012, Isolasi, Karakterisasi Senyawa Aktif dan Uji Farmaka Ekstrak Biji Kebiul pada Mencit (Mus musculus) serta Penerapannya dalam Pembelajaran Kimia di SMAN 1 Bengkulu Selatan, Tesis, Program Pascasarjana Pendidikan IPA Fakultas Keguruan dan Ilmu Pendidikan Universitas Bengkulu, hal $105-107$.

Leboeuf, M., Cave, A., Bhaumik, P.K., Mukherjee, B., Mukherjee, R., 1982, The Pytochemistry of The Annonaceae, Phytochemistry, vol 21: 2783-2813.

Mohamadi, J., Havasian, M.R., Panahi, J., Pakzad, I., 2015, Antifungal drug resistance pattern of Candida. spp isolated from vaginitis in Ilam-Iran during 2013-2014, Bioinformation 11(4): 203-206.

Nuringtyas, T.R., Purwanto, H., dan Rochayati, A., 2007, Senyawa metabolit sekunder pada daun muda dan tua empat jenis tanaman pakan alami ulat atakas (Attacus atlas L.), Berkala Ilmiah Biologi, Vol. 6, No.1: 63-70.

Permatasari, G.A.A.A., Besung, I.N.K., Mahatmi, H., 2013, Daya Hambat Perasan Daun Sirsak Terhadap Pertumbuhan Bakteri Escherichia coli, Indonesia Medicus Veterinus, 2,: 162-169.

Sari, Y.D., Djannah, S.N., Nurani, L.H., 2010, Uji Aktivitas Antibakteri Infusa Daun Sirsak (Annona muricata L.) secara in vitro terhadap Staphylococcus aureus ATCC 25923 dan Escherichia coli ATCC 35218 serta Profil Kromatografi Lapis Tipisnya, Kes Mas Vol 4 No. 3: 218 - 238.

Siswandono dan Soekardjo, B.,2008, Kimia Medisinal, Edisi kedua, Airlangga University Press, Surabaya, hal 18-19.

Suyoso, S., 2013, Kandidiasis Mukosa, Departemen/ SMF Ilmu Kesehatan Kulit dan Kelamin, Fakultas Kedokteran Universitas Airlangga, RSUD Dr. Soetomo Surabaya.

Taylor, L., 2002, Technical Data Report for Graviola, Sage Press Inc.

Wu, F.E., Gu, Z.M., Zeng, L., Zhao, G.X., Zhang, Y., McLaughlin, J.L., and Sastrodihardjo, S., 1995, Two New Cytotoxic Monotetrahydrofuran Annonaceous Acetogenins, Annomuricins A and B, from the Leaves of Annona muricata L., Journal of Natural Products, 58: 830-836. 
